\title{
Méně formalismu, více formace
}

\author{
Karel STARÝ
}

$K_{\text {dyž jsem byl požádán o napsání úvodníku, netu- }}$ šil jsem, jak nesnadný to může být úkol. Po pečlivém přečtení všech článkủ se mi vybavila myšlenka, kterou jsem sice již na několika místech naznačil, ale pořád nemám pocit, že bych se s ní dostatečně vypořádal. Souvisí se slovem forma a jeho odvozeninami. H. Kasíková zmiňuje organizační formy výnky a V. Laufková píše o formativnim hodnoceni. U dalších dvou studií se sice toto slovo explicitně nevyskytuje, ale v jistém smyslu tam prrítomno také je.

Slovo forma je slovo mnohoznačné. Výkladové slovníky uvádějí pět až šest různých významů. Většina nějak souvisí $s$ tvarem, utvářením, ztvárněním apod. Za pozornost však stojí i význam vyjadřující formalismus - když děláme něco „pro formu“, tedy „naoko“, kdy se jedná o předstírání něčeho, co ve skutečnosti tak není. Při výzkumu ve školách jsem se několikrát setkal s tím, že po získání důvěry se mi učitel svěřil, že něco $\mathrm{z}$ toho, co jsem viděl ve výuce, zařadil jen proto, že se domníval, že se to od něj očekává. V kvalitativním výzkumu se tento jev nazývá reaktivita účastníků. Někdy není snadné ji odhalit, jindy učitel sám řekne: „To dělám jen, když přijde inspekce nebo někdo jako vy.“

Pohříchu často se předstírání týkalo právě kooperativního učení, tedy vlastně skupinového vyučování, abych ctil terminologii, kterou H. Kasíková ve své přehledové studii objasňuje. Žáci byli formálně rozděleni do skupin, ale jejich spolupráce byla slabá nebo 
dokonce žádná. Autorka na základě několika empirických studií odhaduje, že práce ve skupinách se vyskytuje v českých školách cca ve $20 \%$ výukového času, kdežto ke skutečnému kooperativnímu učení dochází pouze jen asi ve $4 \%$. Ukazuje se, že kooperativní učení nelze učitelům nařídit, př́ikázat či doporučit. Český člověk si vždy najde cestu, jak všechny př́ikazy obejít a udělat si to po svém. $V$ minulosti s tím koneckonců neudělali nic ani Habsburkové, ani komunisté. Bez vnitřního přesvědčení učitele, že kooperace je něco, co chce u dětí programově rozvíjet, to nemá šanci na úspěch. Potom i pár minut na smysluplné rozdělení žáků do skupin vypadá jako ztráta času.

Dokonce ani když se podaří učitele přesvědčit, ještě zdaleka není vyhráno. Pouze respektováním dalších principů lze kooperativního učení docílit. Dualismus obsahu a formy je pouze teoretický konstrukt, který dobře poslouží $\mathrm{k}$ analýze, ale $\mathrm{v}$ reálném světě jsou obsah a forma přirozeně neoddělitelné. Teprve naplnění formy správným obsahem dává věcem smysl. Když úkolovou situaci pro skupinu žáků připravíte tak, aby ke splnění museli přispívat všichni členové skupiny, vytvoříte sociálni vzájemnou závislost, kde už se nejedná jen o jednu z pozorovatelných organizačnich forem výuky, ale vydáte se směrem ke skutečnému kooperativnímu učení.

H. Kasíková v přehledové studii s velkým nadhledem odkazuje na teoretické základy kooperativního učení, vyjasňuje pojmy, když upozorňuje na některé nepřesnosti v jejich používání - např. na nelogičnost pojmu kooperativni vyučování vzhledem $\mathrm{k}$ tendenci vyučování charakterizovat jako vyučovací činnost učitele. Autorka také uvádí, že kooperativnímu učení se český pedagogický výzkum zatím věnuje pouze okrajově. Teprve další výzkumy by mohly přinést empirická zjištění o tom, jakou měrou je kooperativní učení využíváno $v$ různých stupních a typech škol. Lze tedy pouze spekulovat, jaké existují rozdíly v jeho používání např. mezi učiteli 1 . stupně ZŠ a učiteli gymnázií. Osobně se domnívám, že velké, a bylo by zajímavé ptát se po příčinách.

Slovní základ forma může někoho zmást u pojmu formativní hodnoceni. Podobně jako u kooperace se nejedná jen o formu, o nějaké vnějškově zaznamenatelné chování, ale také o hluboké vnitřní přesvědčení, že každý vzdělávaný jedinec si zaslouží úctu a respekt a v neposlední řadě i dostatek pozornosti. Teprve za tohoto předpokladu mají metody, nástroje a techniky formativního hodnocení smysl. Pojem formativni tak více souvisí s pojmem formace než s pojmem forma. Formace je pojem používaný nap̌r. v náboženské pedagogice a znamená utváření celé osobnosti člověka. Také cílem formativního hodnocení je podporovat celostní rozvoj každého vzdělávaného 
jedince podle jeho specifických potřeb. To nelze, jak upozorňuje v článku V. Laufková, bez pozitivního tř́ídního klimatu. Nejdůležitějším aktérem třídního klimatu je bezpochyby učitel. Kdo měl možnost pozorovat stejnou třídu vyučovanou různými učiteli během jednoho dne, mohl zaznamenat, jak rozdílně se děti chovají v závislosti na tom, jaký učitel je právě vyučuje. Někdy to vypadá, jako by se jednalo o úplně jiné děti. Tř́ídní klima se buduje a trvá dlouhodobě a není jen nutnou podmínkou pro formativní hodnocení, naopak pozitivní klima je také jeho důležitým důsledkem.

$\mathrm{Na}$ celostním pojetí výchovy jsou založena všechna tzv. reformní hnutí. Není tomu jinak ani u hnutí Camphill, které v další studii představuje Š. Klímová. Také v tomto případě bylo na počátku hluboké přesvědčení zakladatelů, že děti se znevýhodněním mají právo na důstojný život. Mohli by něco takového vytvořit, kdyby svou práci nezasvětili tomu, co je přesahuje? Autorka poutavým zpo̊sobem vypráví př́íběh, ve kterém vystupují autentické postavy, jež mají společné to, že touží po lepším světě, než ve kterém žijí. K paradoxům minulého století patří i to, že ve stejné době se formovalo nacistické hnutí, které vyústilo mimo jiné hrůzné činy i v programové vyvražd'ování handicapovaných lidí, založené na učení o tzv. rasové hygieně. Je dobrou zprávou, že už během 2. světové války se našli i v nacistickém Německu lidé, kteří proti tomu veřejně vystoupili a otevřenému vraždění postižených zabránili. Ještě lepší zprávou je, že reformní pedagogické směry přetrvaly, a mohou tak sloužit jako trvalá inspirace pro hlavní vzdělávací proud.

Studie jihočeských autorů o aproximálním numerickém systému na první pohled vypadá jako něco velmi vzdáleného reálnému životu. $\mathrm{Na}$ dovednosti "hrubého odhadu“ je však založena práce mnoha lidí, kteří se nemohou neustále spoléhat na detailní výpočty a přitom musí dělat důležitá rozhodnutí, na kterých závisí výsledek. Matematika je řazena mezi tzv. formálni vědy. Možná i proto v matematice dělat něco jen "pro formu“ postrádá smysl. Poznatky z výzkumu aproximálního numerického systému mohou významně přispět $\mathrm{k}$ poskytování formativni zpětné vazby žákům. Některé oborově-didaktické př́stupy $\mathrm{v}$ matematice např. M. Montessori nebo M. Hejného budování dovedností hrubého odhadu věnují velkou pozornost. Žák potřebuje být precizní při výpočtu i pohlížet na celek s nadhledem hrubého odhadu.

Nové číslo Pedagogiky je vyváženou kombinací přehledových a empirických studií. Společné mají to, že vycházejí z různých oborů - sociální psychologie, teorie výchovy, speciální pedagogiky i neuropsychologie. Ukazuje to, že pedagogika má silný potenciál jiné obory propojovat a integrovat. 
Sympatické také je, že všechny články dovádějí výzkumné téma až k úrovni žáka. A možná i to, že za všemi stojí záměr přijít věcem na kloub a posunout tak vědění a z něho plynoucí intervence ne pro formu, ale pro smysl. Závěrem nezbývá než vyslovit přání, aby i ve vzdělávání bylo méně formalismu a více formace. 